\title{
The relationship between structural factors and interaction quality in Norwegian ECEC for toddlers
}

\author{
Ingrid Midteide Løkken ${ }^{1 *}$, Elisabeth Bjørnestad ${ }^{2}$, Martine L. Broekhuizen ${ }^{3}$ and Thomas Moser ${ }^{1}$
}

${ }^{*}$ Correspondence:
ingrid.lokken@usn.no
${ }^{1}$ Department of Educational
Science, Faculty
of Humanities, Sports
and Education Science,
University of South-Eastern
Norway, Raveien 215,
3184 Borre, Norway
Full list of author information
is available at the end of the
article

*Correspondence: ingrid.lokken@usn.no

Department of Educational

Science, Faculty

of Humanities, Sports

Norway, Raveien 215,

3184 Borre, Norway

is available at the end of the

Springer Open

\begin{abstract}
The purpose of this study was to investigate the relationship between two structural factors of quality: organisation form (stable groups versus flexible groups) and staffchild ratio, in relation to interaction quality in toddler groups in Norwegian early childhood education and care (ECEC). Data were collected from 206 kindergarten groups in the period from 2013 to 2015. Interaction quality was measured through the infant/ toddler environment rating scale-revised subscales, Interaction, listening and talking, and program structure. A two-way MANOVA revealed that organisation form with small, stable groups were related to higher interaction quality, while the staff-child ratio and interaction quality varied depending on different content dimensions. These findings have clear implications for policy and the training of ECEC staff.
\end{abstract}

Keywords: Interaction quality, Structural quality, ECEC, Staff-child ratio, ITERS-R

\section{Background}

As a part of its welfare system, Norway provides universal access to early childhood education and care (ECEC) for all children between the ages of 1 and 5. To provide this access, Norway has undergone considerable structural changes in recent decades (Vassenden et al. 2011). These changes began with the 2003 ECEC settlement, which required municipalities to offer all children a place in ECEC. In 2009, access to a place in an ECEC programme became a legal right for all children. The overall purpose of these settlement initiatives and the establishment of universal access to ECEC was to ensure social equality and secure a good start for all children (Haug and Storø 2013). To meet heightened demand, new and larger ECEC settings were built, group sizes were expanded, the number of children under the age of three attending ECEC settings increased and a new type of organisation, flexible groups was formed (Gulbrandsen and Eliassen 2013). Most of the changes were related to quantity; however, in recent years, quality has appeared more systematically on policy-makers' agendas, especially for infants and toddlers (OECD 2015; Vassenden et al. 2011).

The quality aspects of ECEC are related to children's experiences in ECEC institutions, such as their involvement in interactions and activities that are assumed to be beneficial for their learning and development (Sylva et al. 2006; Thomason and La Paro 2009). The concept of quality in ECEC is multifaceted, although the general consensus is that

(c) The Author(s) 2018. This article is distributed under the terms of the Creative Commons Attribution 4.0 International License (http://creativecommons.org/licenses/by/4.0/), which permits unrestricted use, distribution, and reproduction in any medium, provided you give appropriate credit to the original author(s) and the source, provide a link to the Creative Commons license, and indicate if changes were made. 
quality is related to both structural- and process-quality characteristics. Structural characteristics include such aspects as the staff-child ratio, organisation form, group size, and so on, while process characteristics are related to interactions between caregivers and children (Litjens and Taguma 2010; Phillips et al. 2001; Sanders and Howes 2013), often defined as 'proximal processes' (Bronfenbrenner 1979; Mortensen and Barnett 2015). The NICHD Early Child Care Research Network (ECCRN 2002) illustrated the connections among these quality factors by linking ECEC structural characteristics to proximal processes, and subsequently, children's social and cognitive outcomes. The relationships among the structural- and process-quality characteristics related to children's outcomes have been investigated in several studies (Burchinal et al. 2002; Early Child Care Research Network 2006; Mortensen and Barnett 2015; Phillipsen et al. 1997; Sylva et al. 2011).

A large body of research has found associations between structural- and processquality characteristics. For instance, several studies have found associations between group sizes and ratios and staff-child interactions (Burchinal et al. 2002; De Schipper et al. 2006; Early Child Care Research Network 2006; Phillipsen et al. 1997), and it has been pointed out that the staff-child ratio may be specifically important for young and vulnerable children, who need more one-on-one attention (Munton et al. 2002). In addition, staff members' formal education and training are associated with a higher quality of care and sensitivity in interactions (Burchinal et al. 2002; Phillipsen et al. 1997). Other structural factors, such as years of experience (Phillipsen et al. 1997) and in-service professional development (Slot et al. 2015), have also been related to process quality. Despite this large body of research, however, Slot et al. (2015) claim that the relationship between structural quality and process quality has not yet been fully investigated across a range of cultural contexts, especially in countries outside the US with different structural-quality regulations. This is particularly pertinent in Norwegian ECEC, which includes several structural-quality characteristics that differ significantly from those of other cultural contexts.

Norwegian ECEC is organised differently than ECEC in many other countries. The most prominent differences between Norwegian (or Nordic) ECEC settings and those of other socio-economically comparable countries are that Norwegian ECEC offers universal access; a full-time place for all children from 1 year of age through the start of school; a high rate of enrolment, especially for children between the ages of 1 and 3; low costs (taking into consideration the overall high income level in Norway); and national regulation, a framework plan (Norwegian Directorate for Education and Training 2017) that is binding for all institutions in the country, independent of ownership. Norwegian ECEC also includes two distinct organisational forms (flexible group organisations and more stable group organisations ${ }^{1}$ ) and has less strict regulations in terms of its staffchild ratio (OECD 2017).

Despite Norway's considerable investment in structural changes, there still remains a lack of large-scale studies investigating the relationship between structural- and process-quality characteristics in Norwegian ECEC, especially with respect to toddlers

1 The flexible group organisation and more stable group organisation forms are described in the section 'The Norwegian ECEC context. 
(Bjørnestad et al. 2012). Until recently, studies examining quality in Norwegian ECEC have largely focused on the descriptive characteristics of structural quality, such as ownership, physical environment, demography, group organisation and staff members' levels of education (Gulbrandsen and Eliassen 2013).

The current study aims to decrease the gap in our understanding of the relationship between two specific structural-quality characteristics (organisation form and the staff-child ratio) and process quality (interaction quality) in a country with different structural regulations. This study also contributes to filling the knowledge gap related to the structural changes in Norwegian ECEC settings and the lack of large-scale studies investigating quality ECEC for toddlers. By investigating these relationships, we gain new knowledge on how to organise ECEC to promote higher interaction quality, which could, in turn, positively impact on children's development. Our findings may also provide inspiration for other socio-economically comparable countries that wish to reorganise and improve their ECEC systems.

\section{The Norwegian ECEC context}

As of 2017, 91\% of Norwegian children between the ages of 1 and 5 attend a full-time ECEC programme, and most were enrolled as infants or toddlers. Since the ECEC settlement, the number of toddlers attending ECEC has almost doubled. Nearly as many children (82\%) between 1 and 2 years old attend ECEC (SSB 2017), compared to only $43.9 \%$ in 2004.

There are two main organisational forms of Norwegian ECEC settings: stable group settings and more flexible group settings. Organisational form is the way in which ECEC settings organise their child groups (Vassenden et al. 2011). Stable group settings existed prior to the ECEC settlement, and they are the most traditional and common organisational form in Norway (79\% of ECEC settings) (Gulbrandsen and Eliassen 2013). Stable group settings often have a group organisation wherein each group consists of one large room and additional smaller rooms. Groups of children and staff have clearly defined areas, each with its own interest centres, activity areas and easy-to-access tools and materials (Bjørnestad and Os 2018; Seland 2011; Vassenden et al. 2011). Following the 2003 ECEC settlement, new and larger centres emerged, often organised as flexible group settings (Bjørnestad and Os 2018; Kjørholt and Qvortrup 2011). Flexible group organisation includes several subtypes, such as base, open and zone groups, which all have in common that they are designed to comprise a small home group with larger common shared interest and activity areas where both children and staff members can move around freely. In flexible settings, children can participate in activities located far away from their groups and with other groups (Bjørnestad and Os 2018; Eide et al. 2017; Wilhjelm 2013). One of the concepts underlying more flexible group organisational structures is the perspective of children as competent and capable of choosing where to play, what to play with and whether to create larger and more interesting shared interests 
and activity centres (Seland 2011; Vassenden et al. 2011). The size and number of child groups in each ECEC centre vary in both organisational forms.

There are no binding regulations for staff-child ratios in Norway, where the only ratio that is regulated is the teacher-child ratio. ${ }^{2}$ Groups with children under the age of 3 are required to have at least one educated ECEC teacher (i.e. bachelor's degree level) per seven to nine children (The Ministry of Education and Research 2010). However, the law does not regulate how many assistant teachers a group should include. The OECD (2015) has criticised Norway for this oversight, stating that the lack of regulations concerning the staff-child ratio and group size poses a potential threat to process quality in Norwegian ECEC. Despite the lack of these regulations, it is recommended that there should be a minimum of one staff member (including both assistants and teachers) per three children under the age of three (Øie 2012). Most centres comprise groups with three or fewer toddlers per staff member, but a significant proportion also have more than three toddlers per staff member. The lack of mandatory regulations may cause variations in both structural- and process-orientated factors between ECEC settings, which may in turn have a crucial impact on children's well-being and later outcomes.

\section{Interaction quality}

International studies have noted the importance of interaction quality between ECEC staff and children (Sabol and Pianta 2012). High-quality staff-child interactions influence children's learning, cognitive, social and emotional development (Birch and Ladd 1997; Peisner-Feinberg et al. 2001; Sylva et al. 2003; Thomason and La Paro 2013). Highquality ECEC interactions are also related to fewer behavioural and learning problems later in school (Birch and Ladd 1997; Hamre and Pianta 2005).

Key quality indicators for ECEC interaction quality are a sensitive and responsive staff (Dalli et al. 2011; Helmerhorst et al. 2014; Pianta 1999; Thomason and La Paro 2009) who are physically and emotionally present (Bagdi and Vacca 2005) and create a warm and predictable atmosphere (Gloeckler 2006). Other central indicators for high-quality interactions are inter-subjective attunement (Stern 1985) and joint attention between children and staff (Liszkowski et al. 2007). A high quality of interaction also calls for staff members who are aware of children's different personalities (Dalli et al. 2011) and who include children's perspectives (Pianta 1999).

Toddlers, in particular, need an environment that provides them with the possibility to learn and gain knowledge through relationships, as well as staff members who provide guidance on their behaviour (Dalli et al. 2011). The staff should be close to the children and spend a great deal of their time sitting down on the children's 'physical and spatial' level, providing the children with access to materials and allowing time for transitions (Gloeckler 2006). Staff members should encourage each child to talk about his/her thoughts and feelings (Dalli et al. 2011) and communicate both verbally and nonverbally (Gloeckler 2006). Staff members must also model good language skills (Pianta 1999), which they can do by narrating, explaining and giving advice. Staff should also listen with attention, put words to emotions and call children by their names (Gloeckler 2006).

${ }^{2}$ However, from the first of August 2018, the staff-child ratio is 1:3 for children under the age of three and 1:6 for children older than three. 
These are all elements that are frequently incorporated in observational rating scales assessing the quality of staff-child interactions, such as the infant/toddler environmental rating scale-revised (ITERS-R; Harms et al. 2006). The ITERS-R, and specifically its Interaction, Listening and talking, and Program structure subscales, are the measures used in the current study to investigate staff-child interaction quality.

\section{Structural factors related to interaction quality in ECEC}

Studies have indicated that structural factors such as higher staff-child ratios, smaller group sizes and educated and trained employees are preconditions of high staff-child interaction quality, which, in turn, is associated with better developmental outcomes in children (Phillipsen et al. 1997; Pianta et al. 2005). Higher staff-child ratios mean more staff members per group of children (Munton et al. 2002). Small groups and higher ratios are associated with warmer and more responsive interactions (Burchinal et al. 2002; Early Child Care Research Network 2006; Phillipsen et al. 1997). Other studies have indicated that a higher staff-child ratio is related to higher process quality (De Schipper et al. 2006; Iluz et al. 2016). Nevertheless, some studies have reported weak relationships (Blau 2000) or no associations at all (Pianta et al. 2005) relative to the staff-child ratio.

There has been a lack of research on the importance of ECEC quality for toddlers in Norway and the Nordic countries (Bjørnestad et al. 2012), and very few studies have explored the relative impacts of a flexible group organisation versus a stable groups organisation in Norway (Bjørnestad and Os 2018; Seland 2009; Skalická et al. 2015; Vassenden et al. 2011). Pianta (1999) highlights stability as an essential factor for high-quality interactions. In the Norwegian context, this could have a negative effect on flexible group settings, since one of their aims is flexibility of staff and children. Seland (2009) notes that flexible organisations demand extra effort in terms of staff-child interactions, especially regarding emotional support and sensitive responsiveness. Skalická et al. (2015) revealed that flexible group settings lead to less closeness between staff members and children, as well as more conflicts in interactions between teachers and children later in school.

The current study is part of the Better Provision for Norway's Children (BePro) project, the first large-scale longitudinal study on ECEC quality in Norway (Bjørnestad et al. 2013). Two other studies from the BePro project have also used the ITERS-R. In the first one, Eliassen et al. (2018) used the total ITERS-R score to investigate associations between ECEC quality and children's cognitive development. Their results showed no concurrent associations between children's cognitive development and ECEC quality. In the second study, Bjørnestad and Os (2018) applied the ITERS-R to give a descriptive overview of quality in Norwegian ECEC for toddlers. Their study emphasises that raising the ECEC quality for toddlers in Norway is an urgent task. They also include mean differences between groups based on staff-child ratios and organisation form, although they focus on the ITERS-R total and subscale scores (including more structural aspects) and analyse the structural factors in separate models, without controlling for either of them. As such, it might be that the findings on organisation form are a function of differences in the staff-child ratio, or vice versa. To further disentangle these findings, especially related to staff-child interaction quality, the present study includes organisation form and the staff-child ratio as independent variables in the same model (i.e. with each 
Table 1 Descriptive statistics for structural-quality indicators

\begin{tabular}{lllr}
\hline Organisation form & Staff-child ratio & $\%$ & $\boldsymbol{N}$ \\
\hline Stable groups & & 74.8 & 154 \\
& $\leq 3$ children per staff & 57.1 & 88 \\
& $>3$ children per staff & 42.9 & 66 \\
Flexible groups & & 25.2 & 52 \\
& $\leq 3$ children per staff & 53.8 & 28 \\
& $>3$ children per staff & 46.2 & 24 \\
\hline
\end{tabular}

$\leq 3=$ equal to or less than 3 children per staff; $>3=$ more than three children per staff member

controlling for the other) in relation to differences in individual items of the Listening and talking, Interaction and Program structure subscales. As such, the current study will provide a more detailed picture of exact differences in interaction quality in relation to organisation form (stable versus flexible groups) ${ }^{3}$ and lower versus higher staff-child ratios. Based on previous research, we hypothesise that interaction quality will be higher in groups with higher ratios (e.g. De Schipper et al. 2006; Iluz et al. 2016) and in settings with stable groups (Bjørnestad and Os 2018; Seland 2011).

\section{Methods}

\section{Participants and procedure}

A total of 158 ECEC settings were invited to participate in this study, and 93 agreed to do so. The sampling procedure follows a probability proportional to size selection approach, such that the number of children in a setting determined the setting's probability of being part of the sample. ECEC settings from both rural and urban areas of Norway were included. The non-participation of $41 \%$ of the approached settings could be due to several reasons. Some of the invited settings had no groups that fulfilled the study's criterion of having at least three or more children who were born in 2011 and 2012 and whose parents gave their consent for participation. Other settings reported having undergone structural changes, such as merging two ECEC settings into one.

The sample included both municipal (63\%) and private (37\%) ECEC settings, and the distribution of stable $(74.8 \%)$ and flexible groups $(25.2 \%)$ was in line with national statistics (SSB 2017). The number of groups in each ECEC setting ranged from one to seven, and a total of 206 groups were observed with the ITERS-R. To investigate the effect of the staff-child ratio the number of children per staff member present was used. In line with the policy recommendations proposed by Øie (2012), groups were split into two categories: those with three or fewer children per staff member and those with more than three children per staff member. See Table 1 for the distribution of groups according to organisation form and staff-child ratio.

\section{Measures}

In the BePro project, group-level ECEC quality is assessed using the ITERS-R (Harms et al. 2006), a well-known, frequently used and reliable measure of quality that includes

\footnotetext{
${ }_{3}^{3}$ Whereas Bjørnestad and Os (2018) only categorised the registered "basebarnehager" as flexible groups, we included all centres which are registered differently (e.g. poen and zone groups) than traditional stable groups.
} 
Table 2 Descriptive statistics by organisation form and staff-child ratio

\begin{tabular}{|c|c|c|c|c|}
\hline ITERS-R items & $\begin{array}{l}\text { Stable groups } \\
M(\mathrm{SD})\end{array}$ & $\begin{array}{l}\text { Flexible groups } \\
M(\mathrm{SD})\end{array}$ & $\begin{array}{l}\leq 3 \\
M(\mathrm{SD})\end{array}$ & $\begin{array}{l}>3 \\
M(\mathrm{SD})\end{array}$ \\
\hline \multicolumn{5}{|l|}{ Interaction } \\
\hline Supervision of play and learning & $4.58(2.26)$ & $3.52(2.02)$ & $4.67(2.16)$ & $3.84(2.28)$ \\
\hline Peer interaction & $5.06(1.65)$ & $4.21(1.75$ & $5.18(1.67)$ & $4.41(1.68)$ \\
\hline Staff-child interaction & $5.32(1.74)$ & $3.90(1.75)$ & $5.22(1.82)$ & $4.63(1.83)$ \\
\hline Discipline & $5.02(1.59)$ & $3.98(1.75$ & $5.03(1.64)$ & $4.40(1.70)$ \\
\hline \multicolumn{5}{|l|}{ Listening and talking } \\
\hline Helping children understand language & $5.16(1.48)$ & $4.21(1.76)$ & $5.18(1.50)$ & $4.59(1.70)$ \\
\hline Helping children use language & $5.31(1.68)$ & $3.98(1.53)$ & $5.17(1.68)$ & $4.71(1.79)$ \\
\hline Using books & $3.44(1.97)$ & $2.21(1.66)$ & $3.22(2.035)$ & $3.01(1.88)$ \\
\hline \multicolumn{5}{|l|}{ Program structure } \\
\hline Schedule & $4.88(1.56)$ & $3.81(1.53)$ & $4.78(1.68)$ & $4.39(1.52)$ \\
\hline Free play & $4.00(1.54)$ & $3.00(1.21)$ & $3.78(1.63)$ & $3.71(1.38)$ \\
\hline Group play activities & $4.90(2.17)$ & $4.12(2.06)$ & $4.54(2.28)$ & $4.91(2.00)$ \\
\hline
\end{tabular}

both structural- and process-quality aspects (Hestenes et al. 2007). The ITERS-R comprises 39 items organised into seven subscales. The tool is time efficient and quickly measures central areas of quality in ECEC. Its subscales and items are based on wholegroup observations and are suitable for large-scale research (Bjørnestad and Os 2018).

In the current study, we focus specifically on the Listening and talking, Interaction and Program structure subscales, as these strongly reflect several features of staff-child interactions and address core dimensions of interaction quality presented in other research on interaction quality (Bagdi and Vacca 2005; Dalli et al. 2011; Gloeckler 2006; Helmerhorst et al. 2014; Pianta 1999, Thomason and La Paro 2009). Moreover, these subscales and associated items are strongly represented in the Norwegian Framework Plan (for a detailed comparison, see Bjørnestad et al. in press). The Interaction subscale comprises the items Supervision of play and learning, Peer interaction, Staff-child interaction and Discipline. The Listening and talking subscale includes the items Helping children understanding language, Helping children using language and Using books. Finally, Program structure includes the items Schedule, Free play, and Group play activities. ${ }^{4}$ Items are rated on a scale from 1 to 7 , where 1 is 'inadequate' and 7 is 'excellent'.

Data collectors were certified in the ITERS-R through an online course (Ersi.info 2017), followed by a training in Norwegian ECEC settings. Data collectors were required to achieve a reliability score above $85 \%$ before they could begin to collect data for the project. Data collectors spent four hours in each ECEC setting, beginning around 8:30 in the morning. Following the observation period, the data collector interviewed the ECEC teacher responsible for the group about things they could not observe during the day.

\footnotetext{
$\overline{{ }^{4}}$ Item 32 Provision for children with disabilities was excluded as there were only 24 out of 206 groups for which items was scored.
} 
Table 3 Tests of between-subject effects for the ITERS-R items

\begin{tabular}{|c|c|c|c|}
\hline & & $F$ & $p$ \\
\hline & Items Interaction & & \\
\hline \multirow[t]{4}{*}{ Organisation form } & Supervision of play and learning & 8.79 & .003 \\
\hline & Peer interaction & 9.79 & .002 \\
\hline & Staff-child interaction & 25.42 & .000 \\
\hline & Discipline & 15.52 & .000 \\
\hline \multirow[t]{5}{*}{ Staff-child ratio } & Supervision of play and learning & 6.91 & .009 \\
\hline & Peer interaction & 10.59 & .001 \\
\hline & Staff-child interaction & 5.08 & .025 \\
\hline & Discipline & 7.23 & .008 \\
\hline & Items Listening and talking & & \\
\hline \multirow[t]{3}{*}{ Organisation form } & Helping children understand language & 14.29 & .000 \\
\hline & Helping children use language & 24.97 & .000 \\
\hline & Using books & 16.16 & .000 \\
\hline \multirow[t]{4}{*}{ Staff-child ratio } & Helping children understand language & 6.93 & .009 \\
\hline & Helping children use language & 3.48 & .064 \\
\hline & Using books & 0.47 & .496 \\
\hline & Items Program structure & & \\
\hline \multirow[t]{3}{*}{ Organisation form } & Schedule & 18.35 & .000 \\
\hline & Free play & 18.12 & .000 \\
\hline & Group play activities & 5.44 & .022 \\
\hline \multirow[t]{3}{*}{ Staff-child ratio } & Schedule & 2.72 & .101 \\
\hline & Free play & 0.02 & .891 \\
\hline & Group play activities & 1.67 & .198 \\
\hline
\end{tabular}

\section{Results}

To investigate the associations among organisation form (flexible groups versus stable groups), staff-child ratio and interaction quality, a multivariate analysis of variance (MANOVA) was used with organisation form and staff-child ratio as simultaneously entered independent variables (i.e. controlling for each other) and the items from the three ITERS-R subscales (Interaction, Listening and talking, and Program structure) as dependent variables. Three separate MANOVAs were conducted, one for each subscale of the ITERS-R. See Table 2 for the descriptive statistics of the included ITERS-R items, split by organisation form and staff-child ratio. The descriptive statistics of and correlations among the analysed ITERS-R items for the total group can be found in Additional file 1: Tables $\mathrm{S} 1$ and $\mathrm{S} 2$, respectively.

Using Pillai's trace there was a significant main effect for organisation form on the Interaction subscale, $V=.117, F(4,200)=6.607, p=<.001$ and for the staff-child ratio $V=.063, F(4,200)=3.366, p=.011$. There was no interaction effect between organisation form and staff-child ratio $V=.013, F(4,199)=.669, p=.614$. The between-subject effects on the item level, displayed in Table 3, indicated that the main effect of organisation form and staff-child ratio was significant for all four items. Table 2 shows that both stable group settings and groups with ratios $\leq 3$ scored higher on all four items of the Interaction subscale.

For the items in the Listening and talking subscale, Pillai's trace indicated a significant main effect for organisation form, $V=.147, F(3,201)=11.528, p<.001$, but not for 
staff-child ratio $V=.033, F(3,201)=2.300, p=.079$. There was no interaction effect between organisation form and the staff-child ratio $V=.019, F(3,200)=1.295, p=.277$. The between-subject effects on the item level, displayed in Table 3, indicated that the main effect of organisation form was significant for all three items, and for staff-child ratio only for Helping children to understand language. However, as the overall effect for staff-child ratio was not significant, the between-subject effects for Helping children to understand language should be interpreted with caution. Table 2 showed that stable group settings scored higher on all three items and groups with ratios $>3$ on Helping children to understand language.

For the items in Program structure subscale, Pillai's trace showed a significant main effect for organisation form, $V=.126, F(3,200)=9.595, p<.001$, but not for staff-child ratio $V=.032, F(3,200)=2.170, p=.093$. There was, again, no significant interaction effect between organisation form and staff-child ratio $V=.002, F(3,199)=.159$, $p=.924$. The between-subject effects on the item level (Table 3 ) indicated a main effect of organisation form on all three items, with Table 2 showing that stable group settings scored higher on all three items. No significant effect was found for staff-child ratio on any of the items.

Although the main interests of the current study were the specific ITERS-R subscales and associated items, we also investigated the effects of organisation form and staff-child ratio on the total ITERS-R score. This analysis of variance (ANOVA), with both organisation form and staff-child ratio included simultaneously, showed a main effect of both organisation form, $F(1,203)=24.577, p<.001$ and staff-child ratio, $F(1$, 203) $=4.155, p=.043$. Descriptive statistics show that the mean of the ITERS-R total score was higher in the stable groups $(M=4.05, \mathrm{SD}=.75)$ than the flexible groups 3.44 $(M=3.44, \mathrm{SD}=.78)$, and in the groups with ratios $\leq 3(M=3.99, \mathrm{SD}=.80)$ compared to groups with ratios $>3(M=3.76, \mathrm{SD}=.78)$. Again, there was no interaction effect between organisation form and staff-child ratio $F(1,202)=.506, p=.478$.

\section{Discussion}

The aim of this study was to investigate the relationship between two specific structural factors (organisation form and staff-child ratio) and interaction quality, measured using the ITERS-R (Interaction, Listening and talking and Program structure), which represents some of the core aspects of process quality in Norwegian ECEC for toddlers (Bjørnestad et al. in press). The results of this study show differences in interaction quality in relation to stable versus flexible groups and lower versus higher staff-child ratios. Specifically, stable groups were related to higher quality, while the associations between the staff-child ratio and interaction quality varied depending on different content dimensions.

Regarding organisation form, it seems that flexible groups struggle more to achieve high interaction quality. One explanation for weaker interaction quality in flexible groups could be that it is harder for staff in such settings to create engaging and stimulating environments for high-quality interactions with toddlers due to the open and flexible use of space and rooms and the children's ability to move around freely. Because of these factors, extra organisational effort is needed to create high-quality situations for interactions (Seland 2009). In addition, as children in flexible environments are able 
to move around outside of their groups, staff members may struggle to follow up with each child individually, and there is a risk of less closeness between staff members and children (Skalická et al. 2015). Theory highlights stability as an essential factor in highquality interactions (Pianta 1999) and in establishing the close interactions needed for emotional support and responsiveness (Seland 2009). This may indicate a weakness of the flexible group organisation form for toddlers in Norwegian ECEC, as reflected in their lower interaction-quality scores compared to toddlers in stable groups.

In our findings, the stable groups appeared to be superior to flexible groups in terms of achieving high interaction quality for toddlers. Stable groups allow the staff to be close to the children in all activities, and to see the whole group of children, which might make it easier for staff to be sensitive and responsive (Harms et al. 2006). Thus, it seems that stable groups give staff greater opportunity to use their interaction skills and improve quality.

The staff-child ratio is considered especially important for ECEC quality for young children (Dalli et al. 2011; Munton et al. 2002). Our study supports the idea that higher staff-child ratios (one staff member to three or fewer children) yield higher interaction quality; however, this result was dependent on which items and thus aspects of interaction quality were concerned. The results showed that the staff-child ratio mattered for all items that belong to the Interaction subscale (supervision of play and learning, staff-child interaction, peer interaction and discipline), and also for Helping children to understand language of the Listening and talking subscale. However, the ratio exhibited no clear associations with Helping children to use language or Using books of the Listening and talking subscale, nor with all three items of the Program structure subscale (schedule, free play or group play activities). The positive associations between staff and child ratio and the items in the Interaction subscale and Helping children to understand language could be explained by the fact that it is easier for staff to supervise children and to know when to help, comfort and care for the individuals and the whole group, when there are fewer children per staff member. A higher staff-child ratio also makes it easier to maintain control and guide children's behaviour. By contrast, groups with lower staffchild ratios risk less closeness between staff and children and make it harder for staff to follow up with each child individually. These findings are supported by other research (De Schipper et al. 2006; Iluz et al. 2016).

On the other hand, staff-child ratio was found to have no effect on Helping children use language and Using books in the Listening and talking subscale, nor on all items of the Program structure scale (Schedule, Free play and Group play activities). These specific items relate more strongly to how ECEC settings are organised and structured as prerequisites for interaction quality, and as such are less strongly influenced by the interactions between children and individual staff members. For example, the items reflect the balance in activities throughout the day, the variety of available materials, the amount of play and activities, the flexibility of routines (Harms et al. 2006) and times set aside for transitions (Gloeckler 2006). These dimensions of quality are heavily incorporated in the Norwegian tradition and in the framework plan (Norwegian Directorate for Education and Training 2017); therefore, they are not likely to be affected by the staffchild ratio. 
The findings of this study contribute to the debate on staff-child ratios (Øie 2012) by showing that, for several dimensions of interaction quality with toddlers, a staff-child ratio of three or fewer children per staff member is of great importance. The study also highlights that higher child-staff ratios have differential effects on specific dimensions of interaction quality, with strongest effects for the dimensions that are most closely related to the interactions between children and individual staff members. Other interaction-quality dimensions are influenced by other factors, such as organisation form. The results of this study show that staff-child ratios play an important role in improving some central dimensions of interaction quality.

To ensure high interaction quality in ECEC for toddlers, knowledge on how to organise ECEC settings to promote higher interaction quality, which could, in turn, affect children's development (Burchinal et al. 2002; Early Child Care Research Network 2006; Mortensen and Barnett 2015; Phillipsen et al. 1997; Sylva et al. 2011) is critical. Higher staff-child ratios and a higher prevalence of stable groups may help staff to increase quality by structuring their ECEC programmes and increasing their personal and relational competence. Associations between structural characteristics and process quality and their relations to other structural factors, such as staff experience and training (Burchinal et al. 2002; Phillipsen et al. 1997), and in-service professional development (Slot et al. 2015), should be investigated.

No interaction effects were found between organisation form and the staff-child ratio. This suggests that the effects of organisation form and staff-child ratio are not dependent on one another. For example, the effect of staff-child ratio did not differ for stable versus flexible groups. The findings showed independent effects of organisation form and the staff-child ratio when they were included in the same model (i.e. controlling for each other). This suggests that the staff-child ratio cannot explain the identified effects of organisation form, and organisation form cannot explain the identified effects of the staff-child ratio. However, as this is the first study of its kind in Norway, more research is needed to evaluate the robustness of these findings.

Several limitations of the current study must be taken into consideration. First, the ITERS-R has been criticised for being too superficial and for lacking a main focus on features of quality (Mathers et al. 2012). Furthermore, because the ITERS-R was developed in the US, its relevance for other countries has been questioned (Dickinson 2006). More specifically, some authors have argued that it does not measure interactions in depth (e.g. Helmerhorst et al. 2014). Despite these criticisms, the ITERS-R provides a picture of relevant aspects of ECEC quality for toddlers and has several advantages. It is time efficient and addresses several core areas of ECEC quality (Bjørnestad et al. in press). The measure also assesses interaction quality on a group level, including all staff present in a group of children at the time of measurement.

A second limitation of the study is the relatively small number of observed flexible groups (52 out of 206). The results should be interpreted with this limitation in mind. In addition, several flexible groups registered high scores on interaction quality. Therefore, there is a need for more in-depth qualitative studies to investigate what structural- and process-quality factors distinguish flexible groups with low- and high-quality scores. Findings from such studies might provide highly relevant information for quality improvement for flexible group settings. 
A final limitation of this study is that it does not consider ECEC staff experience. A Norwegian study conducted by Gulbrandsen and Eliassen (2013) showed that the mean age of staff members in small-group ECEC settings is 41-50, whereas, in flexible groups, the mean age is $26-30$. Thus, it could be that it is not the organisation form per se but, rather, the staff's lack of experience that explains the lower interaction quality in flexible groups. Experience has been shown to be important for process quality (Phillipsen et al. 1997), although a very recent OECD (2018) review does not support such an interpretation. Future research should also include other staff-related structural-quality characteristics, such as education, training (Burchinal et al. 2002; Phillipsen et al. 1997) and in-service professional development (Slot et al. 2015) to really disentangle the effects of organisation form and staff-child ratio on interaction quality.

\section{Conclusion}

Our study confirms findings from a number of other studies that there is no clear and simple relationship between structural and process qualities in ECEC. Thus, we suggest that multiple factors and perspectives have to be applied when further analysing the relation between those two forms of quality. By finding unambiguously positive relations in terms of organisational form, and more differentiated relations in terms of staffchild ratio, we conclude that other factors may compensate for structural shortcomings and that further research should include more teacher and institutional related characteristics to disentangle the complex relation between structural and process qualities. Especially aspects of staff experience, in-service-based professional development and pedagogical leadership, including educational values and a focus on child learning and development, should be considered as potential factors that might moderate negative consequences of weak structural quality.

\section{Additional file}

Additional file 1. Additional tables.

Abbreviations

ECEC: Early childhood education and care; ITERS-R: Infant/toddler environment rating scales-revised; MANOVA: Multivariate analysis of variance.

\section{Authors' contributions}

All authors have been involved in the planning and design of this study. IML has conducted the data analysis and prepared the draft of the manuscript. EB supported the writing process in the introduction and discussion, MLB supported the analysis and interpretation of the results, and TM has supported the writing process to the final reading of the manuscript. All authors read and approved the final manuscript.

\section{Author details}

${ }^{1}$ Department of Educational Science, Faculty of Humanities, Sports and Education Science, University of SouthEastern Norway, Raveien 215, 3184 Borre, Norway. ${ }^{2}$ Department of Early Childhood Education, Faculty of Education and International Studies, Oslo Metropolitan University, Pilestredet 52, Oslo, Norway. ${ }^{3}$ Faculty of Social and Behavioural Sciences-Child, Family, and Education Studies, Utrecht University, PO Box 80140, 3508 TC Utrecht, The Netherlands.

\section{Acknowledgements}

This study is a part of the Better Provision for Norway's children in ECEC (BePro) project, with the following Key Investigators: Elisabeth Bjørnestad, Jan Erik Johansson and Lars Guldbrandsen (Oslo Metropolitan University); Marit Alvestad and Eva Johansson (University of Stavanger); Liv Gjems and Thomas Moser (University of South-Eeastern Norway); Edward Melhuish (University of Oxford) and Jacqueline Barnes (Birkbeck University of London). http://www.hioa.no/Forskningog-utvikling/Hva-forsker-HiOA-paa/FoU-ved-LUI/Better-Provision-for-Norway-s-children-in-ECEC [https://goban.no/]. The ITERS-R data have been collected in collaboration with the project "Searching for Qualities". We are grateful to all 
participants in the BePro project: the data collectors, all the ECEC settings, the children and their parents. We also want to thank fellow researchers and reviewers for their thoughtful comments and advices. The Research Council of Norway (BePro 220570) provided support for this research.

\section{Competing interests}

We declare that we do not have competing financial, professional or personal interests that might have influenced the performance or presentation of the work described in this manuscript.

\section{Availability of data and materials}

Not applicable.

Funding

The project is funded by the Norwegian Research Council, under Grant Number 220570.

\section{Publisher's Note}

Springer Nature remains neutral with regard to jurisdictional claims in published maps and institutional affiliations.

Received: 22 December 2017 Accepted: 4 July 2018

Published online: 16 July 2018

\section{References}

Bagdi, A., \& Vacca, J. (2005). Supporting early childhood social-emotional well being: the building blocks for early learning and school success. Early Childhood Education Journal, 33(3), 145-150. https://doi.org/10.1007/s10643-005-0038-y.

Birch, S. H., \& Ladd, G. W. (1997). The teacher-child relationship and children's early school adjustment. Journal of School Psychology, 35(1), 61-79. https://doi.org/10.1016/S0022-4405(96)00029-5.

Bjørnestad, E., Baustad, A. G., \& Alvestad, M. (in press). To what extent does the ITERS-R address pedagogical quality, as described in the Norwegian framework plan? In S. Phillipson \& S. Garvis (Eds.). Teachers and families' perspectives in early childhood education and care: Early childhood education and care in the 21st century (Vol. II). London, UK: Routledge.

Bjørnestad, E., Gulbrandsen, L., Johansson, J-E., \& Os, E., (2013). Foreløpig tilstandsrapport fra prosjeket [Prelimenary report from the project] «Better provision for Norway's children in ECEC: a study of childrens well-being and Development in ECEC». Retrieved from: https://goban.no/files/2013/07/Metodisk-idealkrav-1.pdf. Accessed 11 Dec 2017.

Bjørnestad, E., \& Os, E. (2018). Quality in Norwegian childcare for toddlers using ITERS-R. European Early Childhood Education Research Journal, 26(1), 111-127. https://doi.org/10.1080/1350293X.2018.1412051.

Bjørnestad, E., Samuelsson, I.P., et al. (2012). Hva betyr livet i barnehagen for barn under tre år? En forskningsoversikt [What does life in kindergarten mean for children under the age of three? A research review]. Retrieved from https://www. regjeringen.no/globalassets/upload/kd/vedlegg/barnehager/rapporter20og20planer/forskningsoversikt_barn_ under_tre_aar.pdf. Accessed 11 Dec 2017.

Blau, D. M. (2000). The production of quality in child-care centers: another look. Applied Developmental Science, 4(3), 136-148. https://doi.org/10.1207/S1532480XADS0403_3.

Bronfenbrenner, U. (1979). The ecology of human development. Experiments by nature and design. Cambridge, MA: Harvard University Press.

Burchinal, M. R., Cryer, D., Clifford, R. M., \& Howes, C. (2002). Caregiver training and classroom quality in child care centers. Applied Developmental Science, 6(1), 2-11. https://doi.org/10.1207/S1532480XADS0601_01.

Dalli, C., White, E., Rockel, J., \& Duhn, I. (2011). Quality ECE for under-two year olds: what should it look like? A literature review. Ministry of education. Retrieved from http://thehub.superu.govt.nz/sites/default/files/41442_QualityECE_Web22032011_0.pdf. Accessed 11 Dec 2017.

De Schipper, E. J., Riksen-Walraven, J. M., \& Geurts, S. A. E. (2006). Effects of child-caregiver ratio on the interactions between caregivers and children in child-care centers: An experimental study. Child Development, 77(4), 861-874. https://doi.org/10.1111/j.1467-8624.2006.00907.x.

Dickinson, D. K. (2006). Toward a toolkit approach to describing classroom quality. Early Education \& Development, 17(1), 177-202. https://doi.org/10.1207/s15566935eed1701_8.

Early Child Care Research Network (ECCRN). (2002). Child-care structure $\rightarrow$ process $\rightarrow$ outcome: direct and indirect effects of child-care quality on young children's development. Psychological Science, 13(3), 199-206. https://doi. org/10.1111/1467-9280.00438.

Early Child Care Research Network (ECCRN). (2006). Child-care effect sizes for the NICHD study of early child care and youth development. American Psychologist, 61 (2), 99-116. https://doi.org/10.1037/0003-066X.61.2.99.

Eide, B., Winger, N., Wolf, K. D. \& Dahle, H. F. (2017). Ei linerle vet at hun er ei linerle-En kvalitativ studie av små barns «wellbeing $\gg$ i barnehagen [A qualitative study of toddlers' well-being in kindergarten]. Barn, 35(1), 23-40.

Eliassen, E., Zachrisson, H. D., \& Melhuish, E. (2018). Is cognitive development at three years of age associated with ECEC quality in Norway? European Early Childhood Education Research Journal, 26(1), 97-110. https://doi. org/10.1080/1350293X.2018.1412050.

Ersi.info. (2017). Environment Rating Scales Institute. Retrieved from https://www.ersi.info/aboutus.html. Accessed 11 Dec 2017.

Gloeckler, L. (2006). Teacher/caregiver practices influencing the early development of emotion regulation in toddlers. Retrieved from https://libres.uncg.edu/ir/uncg/f/umi-uncg-1235.pdf. Accessed 10 Oct 2017.

Gulbrandsen, L., \& Eliassen, E. (2013). Kvalitet i barnehager: rapport fra en undersøkelse av strukturell kvalitet høsten 2012 [Quality in kindergartens: A report from an investigation of structural quality authem 2012]. NOVA. Retrieved from http://www.nova.no/asset/6157/1/6157_1.pdf. Accessed 10 Oct 2017. 
Hamre, B. K., \& Pianta, R. C. (2005). Can instructional and emotional support in the first-grade classroom make a difference for children at risk of school failure? Child Development, 76(5), 949-967. https://doi.org/10.111 1/j.1467-8624.2005.00889.x.

Harms, T., Cryer, D., \& Clifford, R. M. (2006). Infant/toddler environment rating scale (Rev ed.). New York, NY: Teachers College Press.

Haug, K. H., \& Storø, J. (2013). Kindergarten-a universal right for children in Norway. International Journal of Child Care and Education Policy, 7(2), 1-13. https://doi.org/10.1007/2288-6729-7-2-1.

Helmerhorst, K. O. W., Riksen-Walraven, J. M., Vermeer, H. J., Fukkink, R. G., \& Tavecchio, L. W. C. (2014). Measuring the interactive skills of caregivers in child care centers: Development and validation of the caregiver interaction profile scales. Early Education and Development, 25(5), 770-790. https://doi.org/10.1080/10409289.2014.840482.

Hestenes, L. L., Cassidy, D. J., Hegde, A. V., \& Lower, J. K. (2007). Quality in inclusive and noninclusive infant and toddler classrooms. Journal of Research in Childhood Education, 22(1), 69-84. https://doi.org/10.1080/02568540709594613.

Iluz, R., Adi-Japha, E., \& Klein, P. S. (2016). Identifying child-staff ratios that promote peer skills in child care. Early Education and Development, 27(7), 1077-1098. https://doi.org/10.1080/10409289.2016.1175240.

Kjørholt, A., \& Qvortrup, J. (2011). The modern child and the flexible labour market: Early childhood education and care. England, Basingstoke: Palgrave MacMillan.

Liszkowski, U., Carpenter, M., \& Tomasello, M. (2007). Pointing out new news, old news, and absent referents at 12 months of age. Developmental Science, 10(2), F1-F7. https://doi.org/10.1111/j.1467-7687.2006.00552.x.

Litjens, I. \& Taguma, M. (2010). Revised literature overview for the 7th meeting of the network on early childhood education and care. Paris, France: OECD.

Mathers, S., Singler, R., \& Karemaker, A. (2012). Improving quality in the early years - A comparison of perspectives and measures. Retrieved from http://www.education.ox.ac.uk/wordpress/wp-content/uploads/2012/03/Early-Years-Quali ty-Research-Brief.pdf. Accessed 11 Dec 2017.

Mortensen, J. A., \& Barnett, M. A. (2015). Teacher-child interactions in infant/toddler child care and socioemotional development. Early Education and Development, 26(2), 209-229. https://doi.org/10.1080/10409289.2015.985878.

Munton, T., Mooney, A., Moss, P., Petrie, P., Clark, A., \&Woolner, J. (2002). Research on ratios, group size and staff qualification and training in early years and childcare settings. Retrieved from http://dera.ioe.ac.uk/4642/1/RR320.pdf. Accessed 11 Dec 2017.

Norwegian Directorate for Education and Training. (2017). Framework plan for kinder-gartens. Retrieved from https://www. udir.no/globalassets/filer/barnehage/rammeplan/framework-plan-for-kindergartens2-2017.pdf. Accessed 15 Nov 2017.

OECD. (2015). Early childhood education and care policy review-Norway. Retrieved from http://www.oecd.org/norway/ Early-Childhood-Education-and-Care-Policy-Review-Norway.pdf. Accessed 15 Nov 2017.

OECD. (2017). Starting strong 2017. Paris, France: OECD Publishing. Retrieved from http://www.oecd.org/publications/start ing-strong-2017-9789264276116-en.htm. Accessed 15 Nov 2017.

OECD. (2018). Engaging young children: Lessons from research about quality in early childhood education and care - starting strong. Paris, France: OECD Publishing. https://doi.org/10.1787/9789264085145-en.

Øie, K. E. (2012). Til barnas beste: Ny lovgivning for barnehagene: Utredning fra utvalg oppnevnt ved kongelig resolusjon [For children's best: New legislation for the kindergarten] (Vol. NOU 2012:1). Retrieved from https://www.regjeringen.no/ globalassets/upload/kd/hoeringsdok/2012/201200556/nou2012_1_tiil_barnas_beste.pdf. Accessed 11 Dec 2017.

Peisner-Feinberg, E. S., Burchinal, M. R., Clifford, R. M., Culkin, M. L., Howes, C., Kagan, S. L., et al. (2001). The relation of preschool child-care quality to children's cognitive and social developmental trajectories through second grade. Child Development, 72(5), 1534-1553. https://doi.org/10.1111/1467-8624.00364.

Phillips, D., Mekos, D., Scarr, S., McCartney, K., \& Abbott-Shim, M. (2001). Within and beyond the classroom door: Assessing quality in child care centers. Early Childhood Research Quarterly, 15(4), 475-496. https://doi.org/10.1016/S0885 $-2006(01) 00077-1$.

Phillipsen, L. C., Burchinal, M. R., Howes, C., \& Cryer, D. (1997). The prediction of process quality from structural features of child care. Early Childhood Research Quarterly, 12(3), 281-303. https://doi.org/10.1016/S0885-2006(97)90004-1.

Pianta, R. C. (1999). Enhancing relationships between children and teachers. Washington, DC: American Psychological Association.

Pianta, R., Howes, C., Burchinal, M., Bryant, D., Clifford, R., Early, D., Barbarin, O. (2005). Features of pre-kindergarten programs, classrooms, and teachers: Do they predict observed classroom quality and child-teacher interactions? Applied Developmental Science, 9(3), 144-159. https://doi.org/10.1207/s1532480xads0903_2.

Sabol, T. J., \& Pianta, R. C. (2012). Recent trends in research on teacher-child relationships. Attachment \& Human Development, 14(3), 213-231. https://doi.org/10.1080/14616734.2012.672262.

Sanders, K., \& Howes, C. (2013). Child care for young children. In B. Spodek \& O. N. Saracho (Eds.), Handbook of research on the education of young children (3rd ed., pp. 355-368). New York, NY: Routledge.

Seland, M. (2009). Det moderne barn og den fleksible barnehagen: en etnografisk studie av barnehagens hverdagsliv i lys av nyere diskurser og kommunal virkelighet [The modern child and the flexible kindergarten: An ethnographic study of the day care life of kindergarten in light of recent discourses and municipal reality] (PhD dissertation). The Norwegian University of Science and Technology, Trondheim. Retrieved from https://brage.bibsys.no/xmlui/bitstream/ handle/11250/268972/287722_FULLTEXT01.pdf?se. Accessed 10 Nov 2017.

Seland, M. (2011). Livet i den fleksible barnehagen: Muligheter og utfordringer i en barnehage i endring. [Life in the flexible kindergarten: Possibilities and challenges in a kindergarten in change]. Oslo: Universitetsforlaget.

Skalická, V., Belsky, J., Stenseng, F., \& Wichstrøm, L. (2015). Preschool-age problem behavior and teacher-child conflict in school: Direct and moderation effects by preschool organization. Child Development, 86(3), 955-964. https://doi. org/10.1111/cdev. 12350 .

Slot, P. L., Leseman, P. P. M., Verhagen, J., \& Mulder, H. (2015). Associations between structural quality aspects and process quality in Dutch early childhood education and care settings. Early Childhood Research Quarterly, 33, 64-76. https:// doi.org/10.1016/j.ecresq.2015.06.001. 
Statistics Norway (SSB). (2017). Barnehager, 2016, endelige tall [Kindergartens, 2016, final numbers]. Retrieved from https:// www.ssb.no/utdanning/statistikker/barnehager/aar-endelige/2017-03-21\#content. Accessed 15 Nov 2017.

Stern, D. N. (1985). The interpersonal world of the infant: A view from psychoanalysis and development psychology. London, UK: Karnac Books.

Sylva, K., Melhuish, E., Sammons, P., Siraj-Blatchford, I., \& Taggart, B. (2011). Pre-school quality and educational outcomes at age 11: Low quality has little benefit. Journal of Early Childhood Research, 9(2), 109-124. https://doi. org/10.1177/1476718X10387900.

Sylva, K., Melhuish, E., Sammons, P., Siraj-Blatchford, I., Taggart, B., \& Elliot, K. (2003). The effective provision of pre-school education (EPPE) project: Findings from the pre-school period. London, UK: Institute of Education, University of London and SureStart.

Sylva, K., Siraj-Blatchford, I., Taggart, B., Sammons, P., Melhuish, E., Elliot, K., \& Totsika, V. (2006). Capturing quality in early childhood through environmental rating scales. Early Childhood Research Quarterly, 21(1), 76-92. https://doi. org/10.1016/j.ecresq.2006.01.003.

The Ministry of Education and Research. (2010). Lov av 17.juni 2005 nr 64 om barnehager (barnehageloven) med endringer, sist ved lov av 18.juni, 2010 nr. 26 [The Kindergarten Act, act no. 64 of June 2005 relating to Kindergartens. Enacted 1. January 2006]. Retrieved from https://lovdata.no/dokument/NL/lov/2005-06-17-64. Accessed 10 Nov 2017.

Thomason, A., \& La Paro, K. M. (2009). Measuring the quality of teacher-child interactions in toddler child care. Early Education and Development, 20(2), 285-304. https://doi.org/10.1080/10409280902773351.

Thomason, A., \& La Paro, K. (2013). Teachers' commitment to the field and teacher-child interactions in centerbased child care for toddlers and three-year-olds. Early Childhood Education Journal, 41(3), 227-234. https://doi. org/10.1007/s10643-012-0539-4.

Vassenden, A., Thygesen, J., Brosvik, S., Alvestad, M., \& Abrahamsen, G. (2011). Barnehagenes organisering og strukturelle faktorers betydning for kvalitet [Kindergartens' organization and structural factors' influence on quality]. Stavanger: International Research Institute of Stavanger. Retrieved from https:/www.regjeringen.no/globalassets/upload/kd/ vedlegg/rapporter/iris_rapport.pdf. Accessed 10 Nov 2017.

Wilhjelm, H. (2013). Barnehagen - hus og hage: fra 1630 til 2010 [Kindergarten —from house to garden]. Oslo, Norway: Gyldendal akademisk.

\section{Submit your manuscript to a SpringerOpen ${ }^{\odot}$ journal and benefit from:}

Convenient online submission

Rigorous peer review

Open access: articles freely available online

- High visibility within the field

- Retaining the copyright to your article

Submit your next manuscript at $\mathbf{s p r i n g e r o p e n . c o m ~}$ 